\title{
入力ゲート付きニューラルネットワークと そのエージェントの行動学習への応用
}

$\begin{array}{llllll}\text { 正員 村 } & \text { 純 一 } & \text { (九州大学) } \\ \text { 非会員 鈴 } & \text { 木 } & \text { 政 史 } & \text { (九州大学) } \\ \text { 正員 } & \text { 平 } \text { 澤 } & \text { 芸太郎 } & \text { (九州大学) }\end{array}$

Neural Networks with Input Gates and Their Applications to Behavior Learning of Agents

Junichi Murata, Member, Masafumi Suzuki, Non-member, Kotaro Hirasawa, Member (Kyushu University)

Neural networks with input gates are proposed for behavior learning of agents. The networks are equipped with gates on their input channels that pass input signals when they are neccesary. A gate opens and closes depending on the current values of input signals. The dependence is automatically determined based on training data. They are applied to behavior learning of agents in the reinforcement learning framework. The gate openings provide the generalized information about the significance of each input signal, which reduces the size of region to be explored and can be exploited to speed up the subsequent learning in other environments.

キーワード : ニューラルネットワーク, 強化学習, 入力選定, 一般化, ルール抽出, 行動制御

Keywords: neural networks, reinforcement learning, input selection, generalization, rule extraction, behavior control

\section{1.はじめに}

エージェントが，与えられたタスクに対して，最適な行 動政策を実現する手段の一つに強化学習がある。強化学習 は報酬を手がかりとして環境に適応する学習であり，エー ジェントを取り巻く環境についての領域知識を必要としな いため，沉用性が高いとされている(1)(2)(3)。

しかし強化学習は試行錯誤を通して学習を行うため，解 の探索空間の大きさが非常に重要な問題となる。この探索 圶間の大きさはエージェントの状態または状態と行動の組 により決定される。状態は入力情報によって決定され，各 入力パターンごとに状態の值が割り当てられる。したがっ て, 状態空間の次元は考慮する入力の個数によって決まり, 状態空間の各次元に対応する各軸方向の長さは各入力が取 り得る値の個数によって決まる。特に入力が連続值をとる 場合は，長さは無限となる。これらの次元と長さの両方で 規定される状態空間の大きさが十分に大きくないと，状態 が大雑把にしか識別されず学習自体が成功しない可能性が ある。また逆に状態空間が大き過きる場合，探索空間が大 きくなり，最適政策を学習するのに多くの時間を要するこ とになる。状態空間を適切な大きさにするためには，必要 な入力のみを選択して用い, かつ入力が取り得る值の候補
が多い場合にはそれらの值を適切に統合して取り扱うこと が必要である。

入力の取り得る値の候補が多い場合の対処法として, 関数 近似や coarse coding を用いることが提案されている(3) (4)。 一方, 必要な入力を選択することは, 強化学習のフレーム決 定問題として取り扱われており，統計的な方法(5)や，遺伝 的アルゴリズムを用いた進化論的手法が提案されている(6)。 本研究では, 強化学習の代表的な実現手法である Q 学習 (7) により得られた $Q$ 值をもとに，合理的な判断に基ついて適 切なフレームを決定する。

提案手法の特徵は，(1) ある入力の要不要が他の入力の 值に依存して変わる場合，その依存性をも捉えて利用する こと，(2) ある一つのタスクのみに適した状態空間を求め るのではなく，類似の複数の夕スクに適用可能な情報を抽 出して利用すること，の2 点である。上述のように，状態 空間の適切な決定には, 入力变数の適切な選択 (状態空間 の次元の決定) と入力值の適切な統合 (状態空間の各軸方向 の大きさの決定)とが必要である。しかし，本研究では，こ の両者を行って特定のタスクに特化した結果となってしま うことを避けるために，入力の選択とその状況依存性の把 握を行うに留める。

状況に応じて入力情報を使い分けることは，我々人間も 
行っている。人間は明るい部屋では主に視覚的な入力情報 に基づいて行動し，暗い部屋では手に触れる物体の感覚な どを入力情報として行動する。このような視覚と触覚の使 い分けは，行動の目的すなわち達成すべき夕スクの種類に 関係なく有用であり，一度獲得されると多くの夕スクに利 用することができる。このことは，状況依存性を考虑した 入力の選択結果を類似タスクに共通する特徵として抽出し， 利用しようとする本研究の立場を，経験的に支持している と言える。

状況依存性を持つ入力の選択を行う手段として，入力ゲー ト付き RBF ネットワークを用いる。著者は入力ゲート付き ニューラルネットワークを先に提案した ${ }^{(8)}$ 。これは、シグ モイド関数からなる階層型ニューラルネットワークの入力 端に，入力信号の伝達を当該入力および他の入力の值に応 じて制御する入力ゲートを設け，状況に依存した適切な入 力の要不要の判定機能を学習によって獲得するネットワー クである。本論文では，強化学習で獲得する $Q$ 值を表現す るために， RBFネットワークに入力ゲートを付加し，エー ジェントの行動学習に適用することを提案する。先に述べ た適切なフレームの決定は入力ゲートの開閉によって実現 される。入力ゲートが入力情報の必要性を判定し，その入 カの学習システムへの伝達を状況に応じて制御する。これ により探索空間を適切な範囲に制限することができる。

行動を決定する際にどの入力が必要/不要であるかを，あ るタスクに関する学習によって入力ゲートの動作として獲 得し，これを利用して類似のタスクが課せられた際の行動 学習の高速化を図る。これは，複数の夕スクに共通する一 般的特徴を学習によって獲得し，それを利用することに相 当する。また学習成果を人間が見て解釈を行う際に，学習 されたゲートの動作を調べることにより，それを容易にす る效果も期待できる。

\section{2. 強化学習}

$\mathrm{Q}$ 学習(7)では状態 $s$ と行動 $a$ の組に対する評価を表すも のとして $Q$ 值を導入する。ここで $Q$ 值とは現時刻から将 来にわたって得られる報酬の和を推定した值である。時刻 $t$, 状態 $s_{t}$ において, 行動 $a_{t}$ を選択した結果, 状態 $s_{t+1}$ と なり，報酬 $r_{t}$ が得られたとすると， $Q\left(s_{t}, a_{t}\right)$ を推定するた めの $Q$ 值の变更は次のように行われる。

$$
\begin{aligned}
& Q\left(s_{t}, a_{t}\right):=Q\left(s_{t}, a_{t}\right) \\
& +\alpha\left[r_{t}+\gamma \max _{a} Q\left(s_{t+1}, a\right)-Q\left(s_{t}, a_{t}\right)\right]
\end{aligned}
$$

あるスケジュールにしたがって学習率 $\alpha$ 減少させ，多数 の試行の徯に $Q$ 值吕収束すると，各状態において最大の $Q$ 值を与える行動の選択が最適政策となることが証明されて いる。また $\gamma(0<\gamma<1)$ は割引率であり, どのくらい先の 将来の報酬まで考虑するかを表すパラメータである。

$\langle 2 \cdot 1\rangle \quad E$-greedy 学習が不十分な場合においても $Q$ 值が最大となる行動を選択し続けると，現時点での政策よ り優れた政策が存在していても政策の改善を図ることがで

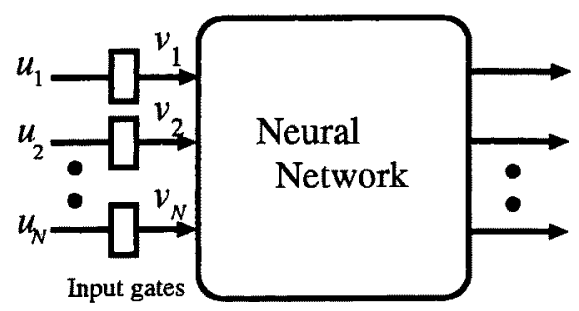

図 1 入力ゲート付きニューラルネットワータ

Fig. 1. Neural network with input gates.

きない。この改善を図る手段の一つとして $\varepsilon$-greedy ${ }^{(3)}$ があ

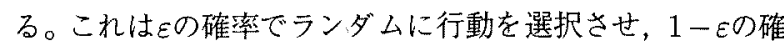
率で $Q$ 值が最大となる行動を選択するというものであり， $Q$ 学習において，環境の探索とこれまでに獲得した $Q$ 值す なわち経験の活用のバランスをとるための一般的な手法で ある。本諭文では，Q学習での行動選択にこの 用いることにする。

$\langle 2 \cdot 2\rangle$ 学習の高速化および行動ルールの一般化 前述 したように，エージェントの状態は適切な入力情報によっ て決定されることが望ましい。必要以上の入力をエージェ ントに与えた場合, 状態空間の次元が增加する。これによ り本質的には一つの状態とすべきものが, 状態空間中で不 要な軸方向に分岐して複数の状態として取り扱われること が起こりうる。これら複数の状態のそれぞれについての経 験はそれぞれ別のものとして扱われることになり，適切な $Q$ 值の推定值を得るためにはより多くの経験が必要とさ れる。これは結果として学習の低速化を引き起こす原因と なる。

しかし入力ゲート付きニューラルネットワークを用いる 本手法では，必要以上の入力を用意していた場合において も，ゲートが閏じるという動作により，不要な入力によっ て複数の次元にまたがっていた状態の次元を落すことが可 能になる。さらに状況によって要不要が変化する入力に関 しても，必要な場合のみ用いることができる。

エージェントの行動選択という観点から見てみると，不 要な入力によって分岐された複数の状態に対する個々の経 験を一つの状態に対する経験とみなすことができるため， 獲得された行動ルールは一般化された行動ルールであると いえる。またこれらの経験は一つの同じ状態に対する複数 の学習データとすることができるため，等佃的に数多くの 学習データを利用することになり, 学習の高速化も期待で きる。

3. 入カゲート付きニューラルネットワーク

〈3.1〉 入力ゲートの構造 入力ゲート付きニューラル ホットワークでは，図 1に示すように各ゲートに対応する 入力信号 $u_{j}$ をゲートの開度 $G\left(z_{j}\right)$ に応じてネットワータ 本体に伝達する。

$$
v_{j}=G\left(z_{j}\right) u_{j}
$$




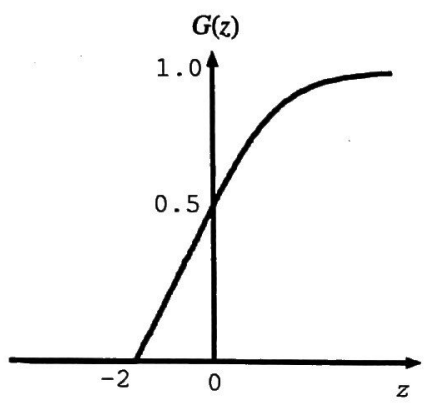

図 2 ゲート関数

Fig. 2. Gate function.

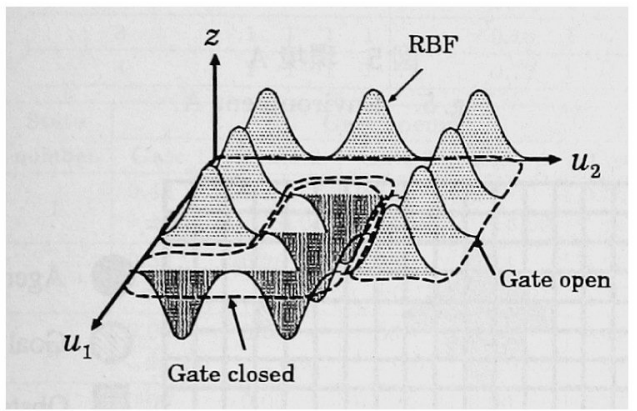

図 3 ゲート開閉を決定する入力空間の RBF に よる分割

Fig. 3. Division of input space into gate-open and gate-closed regions by RBFs.

ゲートの開度を決定する関数 $G\left(z_{j}\right)$ として次式を用いる。 また $G\left(z_{j}\right)$ の概形を図 2 に示す。

$$
G\left(z_{j}\right)= \begin{cases}0, & z_{j} \leq-2 \\ 0.5+0.25 z_{j}, & -2<z_{j} \leq 0 \\ \frac{1}{1+\exp \left(-z_{j}\right)}, & 0<z_{j}\end{cases}
$$

$G\left(z_{i}\right)>0$ のときはゲートが開いていることに相当し，そ のゲートを通過する入力は必要であることを示す。また $G\left(z_{i}\right)=0$ のときはゲートが閉じていることに相当し， 対応する入力が不要であることを示す。

ゲートの開閉は, その時点での入力 $\boldsymbol{u}=\left[u_{1} \cdots u_{N}\right]^{T}(N$ は入力数) の值によって制御する。したがって, 可能な全入 カの值に対してゲートの開または閉のいずれかを割り当て る必要がある。現実には, 多くの場合近接した入力では望 ましいゲートの開閉は同じになると考えられる。一方，式 (3)の $G\left(z_{j}\right)$ を用いると， $z_{j} \leq-2$ のときにゲートは閉じ, $z_{j}$ が-2よりも十分大きいときには開くことになる。そこ で, 入力と $z_{j}$ の間の関係を規定する関数は, 互いに近接し た入力からなる集合の一つ一つに対して，-2 以下あるいは -2 より十分に大きい $z_{j}$ のいずれの值も割当て可能なもの である必要がある。ここでは, 局所的な台をもつ関数であ るガウス型の Rasial Basis Function(RBF) を用いて，j 番目の入力ゲートの開度を決定する $z_{j}$ を次式に従って定め ることにする。これにより図 3に示すような入力空間の任
意の分割が可能となる。

$$
\begin{aligned}
& z_{j}=\sum_{k=1}^{K} a_{j}^{k} \phi_{j}^{k}(\boldsymbol{u}) \ldots \ldots \ldots \ldots \ldots \ldots \ldots \ldots \ldots \ldots \ldots \\
& \phi_{j}^{k}(\boldsymbol{u})=\exp \left\{-\frac{\left(\boldsymbol{u}-\boldsymbol{c}_{j}^{k}\right)^{T} \Sigma^{-1}\left(\boldsymbol{u}-\boldsymbol{c}_{j}^{k}\right)}{2}\right\}
\end{aligned}
$$

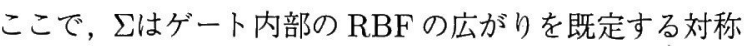
正定值定数行列，また $c_{j}^{k}$ は各 $\mathrm{RBF} \phi_{j}^{k}$ の中心位置，Kは一 つのゲートに含まれる RBF の個数である。係数 $a_{j}^{k}$ を適切 に学習することでゲートの開閉状況を任意に決めることが できる。また $c_{j}^{k}, \Sigma^{-1}$ はあらかじめ設定しておき，学習の 対象としない。学習されたパラメータあるいはゲートの動 作からどのような状況ではどの入力が必要かまたは不要か を容易に知ることができる。係数 $a_{j}^{k}$ の学習については 4 章 で述べる。

\section{4. 入カゲート付き NNのエージェントの行動学習 への応用}

本論文では $Q$ 值を RBF ネットワークによって近似する。 $\mathrm{RBF}$ ネットワークの基底関数として，ガウス型 $\mathrm{RBF}$ を用 いる。図 4に示すようにネットワークの入力は感覚入力と し, 出力は可能な行動に対する $Q$ 值とする。いま, 感覚入 力を $\boldsymbol{u}$, 入力ゲートの出力を $\boldsymbol{v}$, そのときのネットワークの 出力が $Q_{i}(i=1 \cdots L)$ であるとすると, 入出力関係は次の 式で表される。

$$
Q_{i}=\sum_{m=1}^{M} w_{i m} \exp \left\{-\sum_{n=1}^{N} \frac{\left(v_{n}-\mu_{m n}\right)^{2}}{\sigma_{m n}^{2}}\right\}
$$

ただし $M$ は $\mathrm{RBF}$ ノード数, $w_{i m}$ はそのノードの重み， $\mu_{m n}$ はその RBF の中心值， $\sigma_{m n}$ は RBF の広がりを表すパ ラメータである。未経験の感覚入力があった場合, 新たにそ の入力に対応する RBF を配置する。 $\boldsymbol{\sigma}_{m}=\left[\sigma_{m 1} \cdots \sigma_{m N}\right]^{T}$ を予め小さい值に設定しておくと，各状態に対してほぼ一 つのノードが対応することになるので, 出力 $Q_{i}$ はこのノー ドの重み $w_{i m}$ にほほ等しくなる。そこで $Q_{i}$ 值の更新は式 (1)の $Q$ をwに置き換えた式に従って行うことができる。

学習の手順は二つの学習フェーズにより構成される。ま ずフェーズ Iでは全入力を用いて $\mathrm{Q}$ 学習を行う。 $Q$ 值は入 カゲート付きニューラルネットワークで表され，その重み を上述のように式 $(1)$ に従って更新する。このときゲート パラメー夕 $a_{j}^{k}$ の值は 0 に設定しておく。これは式 $(2) \sim(5)$ からゲートが開いた状態に相当する。

次にフェーズ II は，入力ゲートのゲートパラメータ $a_{j}^{k}$ のみについての学習を学習係数を $\eta$ とした BP(Back Propagation) 法により行う。ゲートパラメータ $a_{j}^{k}$ の学習の目 的はフェーズ I で全入力変数を用いるという前提で達成し たネットワークの性能を損なわない範囲内で, 可能な限り ゲートを閉じることである。そこで次式に示す評価関数 $E$ を最小化するように学習を行う。 $Q_{k}$ teach はフェーズ Iで得 


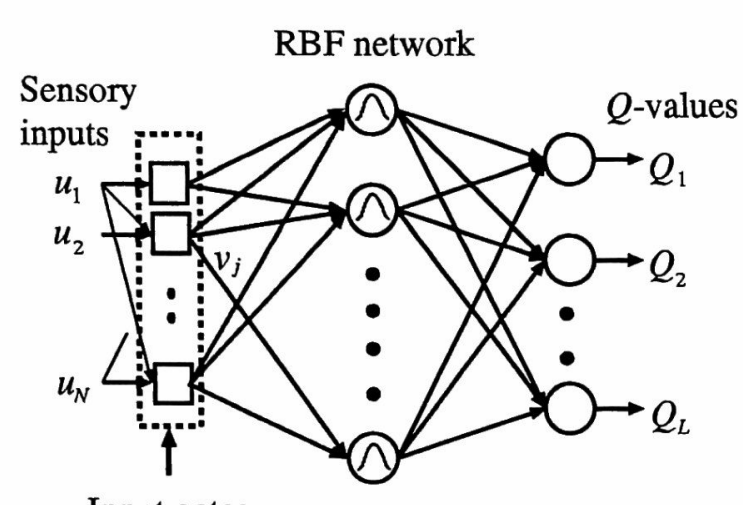

Input gates

図 4 エージェント行動学習用入力ゲート付き $\mathrm{RBF}$ ネットワーク

Fig. 4. RBF networks with input gate for behavior learning of agents.

られたネットワークからの出力である。 $E_{1}$ は $Q$ 值に関す る誤差項, $E_{2}$ はゲートの開度 $G\left(z_{j}\right)$ の大きさを表す項で ある。

$$
\begin{aligned}
& E=E_{1}+\beta E_{2} \quad(\beta>0) \cdots \\
& E_{1}=\sum_{k} \frac{1}{2}\left(Q_{k}-Q_{k} \text { teach }\right)^{2} \\
& E_{2}=\frac{1}{2} \sum_{i}\left(G\left(z_{i}\right)\right)^{2} \ldots \ldots
\end{aligned}
$$

$\mathrm{BP}$ 法による学習は微分值を用いるので, ゲートパラメー 夕の変化範囲に対して Eが連続である必要がある。しかし， フェーズIでの学習を容易にするため RBF の広がり $\sigma_{m}$ は 小さい值としている。そこで BP 法によるゲートパラメー 夕の学習を行う前に $\boldsymbol{\sigma}_{m}$ を $\mathrm{Q}$ 值があまり変動しない範囲で 大きくすることにより RBF 間を滑らかに補間する。

\section{5. シミュレーション}

〈5・1〉条 件 エージェントが学習する環境を図 5 , 図 6 に示す。環境にはゴールとなる光源と障害物 (光を遮 る)があり，ここでエージェントは図7の左図に示すような 周囲のマスの障害物の有無, 光の強さ, および図7の右図の $1 ， 2 ， 3 ， 4$ に示すような光の届く打拉よその向きを知覚す ることができこれらを入力として障害物を迁回しながら， 光の発しているゴールへ最短ステップ (時間単位) で到達す るタスクを達成する。光の強さは連続值であり -1 から 1 ま での值をとる。また障害物情報は離散值であり, 障害物が あるときはー1，ないときは 1 の值をとる。ただし，図 7 の 左の図におけるマス目の障害物の有無の情報 (Gate1〜4), および光の強さ (Gate5) に関してはゲートを介してネット ワークに入力されるものとする。ゲートの開度を決定する 入力は, Gate1 では Gate2，3，4，5を通してネットワーク へ伝達される入力, Gate5 では Gate1，2，3，4 通して

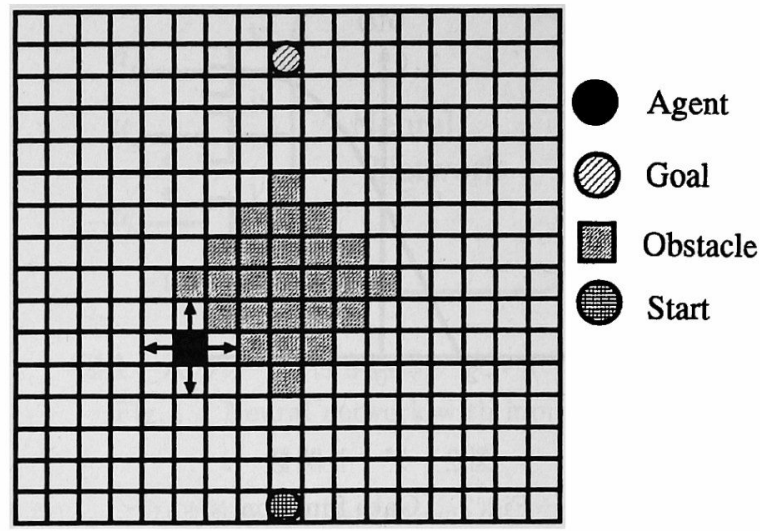

図 5 環境 $\mathrm{A}$

Fig. 5. Environment A.

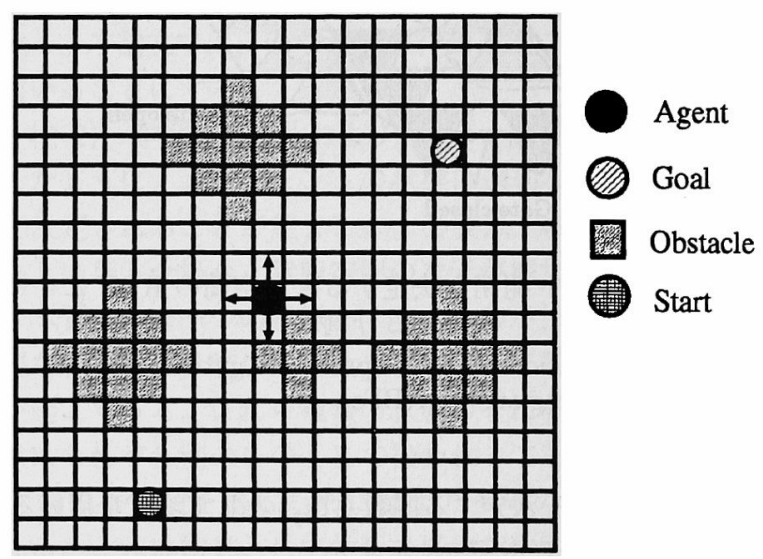

図 6 環境 $B$

Fig. 6. Environment B.
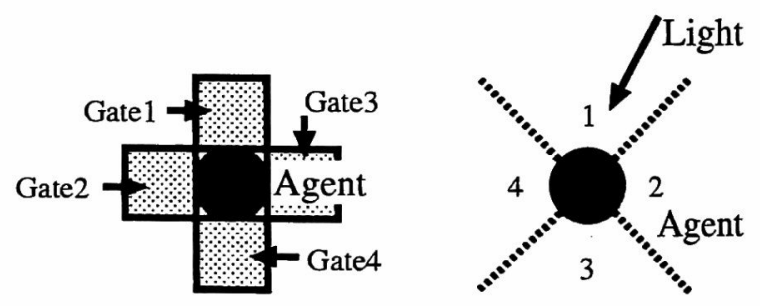

図 7 環境から受け取る入力情報

Fig. 7. Agent's inputs from the environment.

ネットワークへ伝達される入力である。また，行動として は上下左右の方向に 1 時刻につき 1 マス動くことができる。 報酬は，通常は action penalty としてー1を与える。特 に，設定したエリアの外にでる行動を選択したとき，およ び障害物にぶつかる行動を選択したときはー2を与える。た だしゴールに到達した時のみ上記のような罰は与えず, 報 酬は 0 とする。

学習とその評価は以下の手順で行う。 
表 1 設定パラメータ

Table 1. Paramters.

\begin{tabular}{c|c|c|c|c}
\hline$\alpha$ & $\gamma$ & $\epsilon$ & $\beta$ & $\eta$ \\
\hline 0.1 & 0.98 & 0.1 & 0.5 & 0.01 \\
\hline
\end{tabular}

表 2 典型的な状態におけるゲートの開度状況 Table 2. Description of typical states and their gate openings.

\begin{tabular}{c|rrrr|cr}
\hline \multirow{2}{*}{ State number } & \multicolumn{5}{|c}{ State description } \\
\cline { 2 - 6 } & \multicolumn{2}{|c|}{ Obstacles } & $\begin{array}{l}\text { Light strength and } \\
\text { direction }\end{array}$ \\
\hline 1 & -1 & 1 & 1 & 1 & -1.00 & NA \\
\hline 2 & 1 & 1 & 1 & 1 & -0.14 & 1 \\
\hline 3 & 1 & 1 & 1 & 1 & 0.19 & 4 \\
\hline 4 & 1 & 1 & 1 & 1 & 0.72 & 1 \\
\hline
\end{tabular}

\begin{tabular}{c|c|c|c|c|c}
\hline \multirow{2}{*}{$\begin{array}{c}\text { State } \\
\text { number }\end{array}$} & \multicolumn{5}{|c}{ Gate opening } \\
\cline { 2 - 6 } & Gate 1 & Gate 2 & Gate 3 & Gate 4 & Gate5 \\
\hline \multirow{2}{*}{1} & 0.43 & 0.43 & 0.43 & 0.00 & 0.50 \\
& \pm 0.05 & \pm 0.05 & \pm 0.05 & \pm 0.00 & \pm 0.00 \\
\hline \multirow{2}{*}{2} & 0.36 & 0.26 & 0.26 & 0.14 & 0.50 \\
& \pm 0.08 & \pm 0.13 & \pm 0.13 & \pm 0.07 & \pm 0.00 \\
\hline \multirow{2}{*}{3} & 0.00 & 0.05 & 0.05 & 0.00 & 0.49 \\
& \pm 0.00 & \pm 0.07 & \pm 0.07 & \pm 0.00 & \pm 0.02 \\
\hline \multirow{2}{*}{4} & 0.00 & 0.00 & 0.00 & 0.00 & 0.37 \\
& \pm 0.00 & \pm 0.00 & \pm 0.00 & \pm 0.00 & \pm 0.22 \\
\hline
\end{tabular}

・一つのタスク (環境 A)について入力ゲートが開いた 状態で，入力情報をすべて用い，Q值を表現する入力 ゲート付き $\mathrm{RBF}$ ネットワークを, 通常の $\mathrm{Q}$ 学習アル ゴリズムを用いて学習する(学習フェーズ I)。

・学習で得た入力ゲート付き $\mathrm{RBF}$ ネットワークの入力 ゲートを，4章で述べたアルゴリズムによりダートが 閉じるように学習する(学習フェーズ II)。

・学習された入力ゲートを用い，すなわち必要な入力の みを対象として，同夕スク（環境 A）または類似した 他のタスタ (環境 B)に対して，Q学習を行う(学習さ れたゲートの評価)。

各ゲートはいずれも 32 個の RBF を持ち, 中心位置 $c$ は $(-1,-1,-1,-1,0),(-1,-1,-1,-1,1), \cdots,(1$

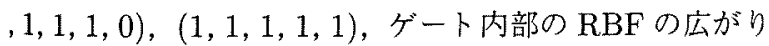
を表す行列 $匚$ は $\operatorname{diag}(0.125, \cdots, 0.125)$ とする。また RBF ネットワーク本体の RBF の広がりを表す係数の初期值を $\sigma=0.1$, 他のパラメータを表1のように設定した。

$\langle 5 \cdot 2\rangle$ 結 果

$\langle 5 \cdot 2 \cdot 1\rangle$ 入カゲートの開度についての考察人間の 視点加ら見ると, 光を知覚できればその情報をもとに最適 な行動を学習し, 知覚できなければ障害物情報をもとに最 適な行動を学習したほうが効率よく最適な行動方針を獲得 できると考えられる。表 2 に環境 Aにおいて学習を行った ゲートの代表的な状態に対する開度を示す。この表を含め, 以下に示す結果は，全て乱数系列が異なる5通りのシミュ レーション結果をまとめたものである。表 2 にはゲート開 度を平均值士標準偏差の形式で表示している。光が感覚で
きる状態では表 2 中の状態 3,4 のようなゲート開度を示 す場合が多いという結果が得られた。状態 3 では，光が見 えるため光の強さおよび方向のみをもとに状態を決定でき ることを示しており，さらに状態 4 では，光の強さの入力 ゲートも閉じる場合がある。この状態 4 では，光の来る方 向がエージェントにとって上側にあり，環境 Aでは，この ような場合, 光の強さに関係なく方向のみによって最適行 動を決定できる場合もあることを示している。また，状態 1 のような光が見えない状態では光の強さに設けたゲート (Gate5) が閉じることはなかった。

このことからエージェントが光を知覚できる状態では主 に光の強さ，方向に関する情報から行動を決定しているこ とが分かる。光に関する情報のほうが障害物情報に対して 情報の優先度が高いといえる。これは人間の視点からみた 入力情報の使い分けと同様の結果であることから，入力情 報を人間の解採しやすいものとすることができていること が分かる。

〈5・2・2〉 入カゲートによる学習の高速化についての検 証学留の高速化に対する効果を確認するために, 環境 A でフェーズIとフェーズ II を行ってゲートの学習を完了 した後，一旦 $Q$ 值はりセットし，学習した入力ゲートを用 いて再び環境 $\mathrm{A}$ で $\mathrm{Q}$ 学習を行った。これは，学習された ゲートの効果を推し量るためであり，もし状況に応じて状 態を適切に分割することができていれば，最初に行う $\mathrm{Q}$ 学 習に比べて入力ゲート学習後の Q 学習は高速化するはずで ある。

図 8にスタートからゴールまでに要したステップ数の, 100 エピソードごとの平均值を示す。また，図 9 は各状態 での $Q$ 值が最大となる行動が, 最適政策と一致していたエ ピソード数を 100 エピソードごとにカウントしたものであ る。いずれも乱数系列の異なる 5 回の計算結果の平均值を 示している。図 8, 図 9から, 入力ゲート学習後の Q 学習 のほうが早いエピソードで最適政策を獲得できていること が分かる。確率的行動選択である -greedyに起因する変動 があるため定量的で正確な比較は難しいが，この図におい て，スタートからゴールまでの平均所要ステップ数が最短 ステップ数 22 の 1.5 倍を初めて下回ったエピソードを比較 すると，提案手法では 900 エピソード，通常のQ Q学習では 1100 エピソードであった。これから計算される学習速度の 短縮率は $82 \%$ である。また，最適政策の獲得頻度が初め て 40\%を上回ったのは，提案手法 500 エピソードに対し， $\mathrm{Q}$ 学習 2500 エピソードであった。これを指標とすれ壮学 習時間が $25 \%$ に短縮されたことになる。以上より，同じ夕 スクに対して入力ゲートが状態の分割を適切に行うことに より学習が高速化できて拉り，入力ゲートの効果を確認す ることができた。

〈5・2・3〉 類似のタスクへの入カゲートの効果について の検証次に類似の夕スクに対しての入力ゲートの効果 を検証する。この場合, 環境 $\mathrm{A}$ と環境 $\mathrm{B}$ は障害物の形状 などが類似している。また光が知覚できたときは光に関す 


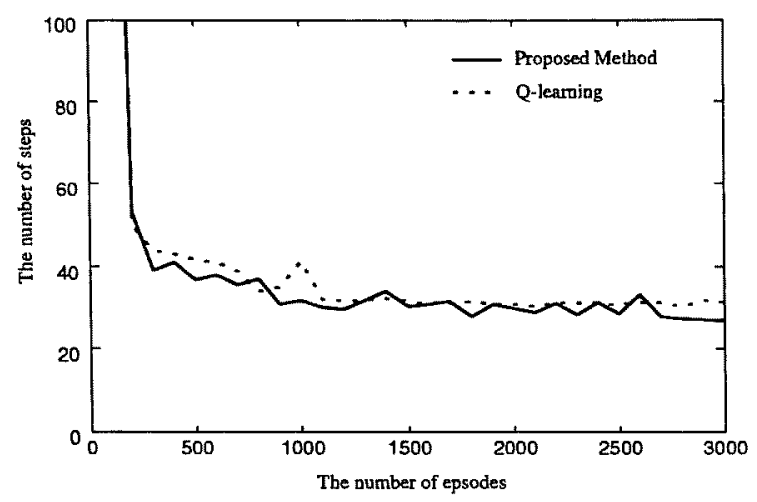

図 8 平均所要ステップ数（環境 A)

Fig. 8. Average number of required steps (Environment $\mathrm{A}$ ).

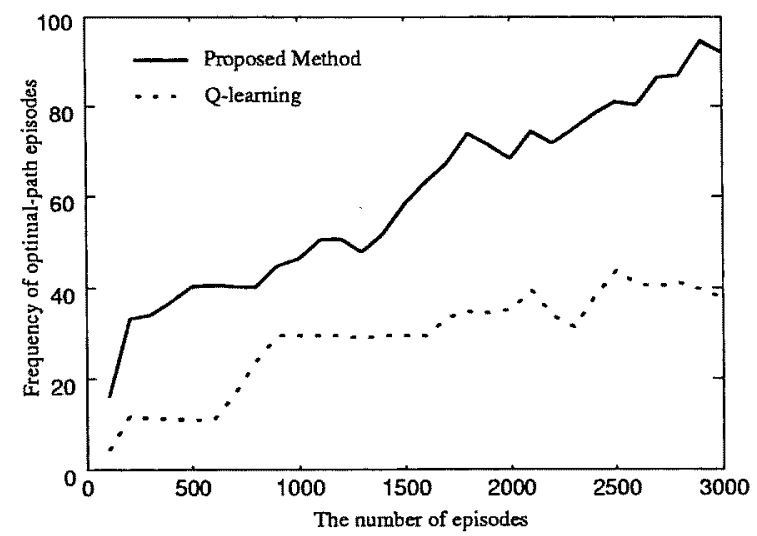

図 9 最適政策の獲得頻度（環境 A）

Fig. 9. Frequency of acquiring the optimal policy (Environment A).

る情報をもとに，知覚できないときは障害物情報をもとに 行動を学習したほうがよいという点は，環境 A，Bのそれ ぞれに共通している。既に環境 A で学習された入力ゲート を用い，Q值はりセットして環境 $\mathrm{B}$ に対しての $\mathrm{Q}$ 学習を 行う。このような学習済入力ゲートを用いた $\mathrm{Q}$ 学習と, 入 カゲートを用いない通常の Q 学習とで両者の学習効率を比 較した。

前節同様に平均所要ステップ数, 最適政策の獲得の速さ を示したグラフを図 10, 図 11に示す。これらも乱数系列の 異なる 5 ケースの平均値である。図 10, 図 11から, 入力 ゲートの学習を行うことにより，類似したタスクに関して も速やかに学習できていることが分かる。平均所要ステッ プ数が最短ステップ数 22 の 1.5 倍を初めて下回ったエピ ソードは, 提案手法 500 エピソード，Q学習 600 エピソー ド，また，最適政策獲得頻度が $80 \%$ を初めて上回ったエピ ソードは，それぞれ 600 エピソード，1100 エピソードで あった。これらを用いると，17ないし $45 \%$ 程度の時間短縮 が行われていることになる。

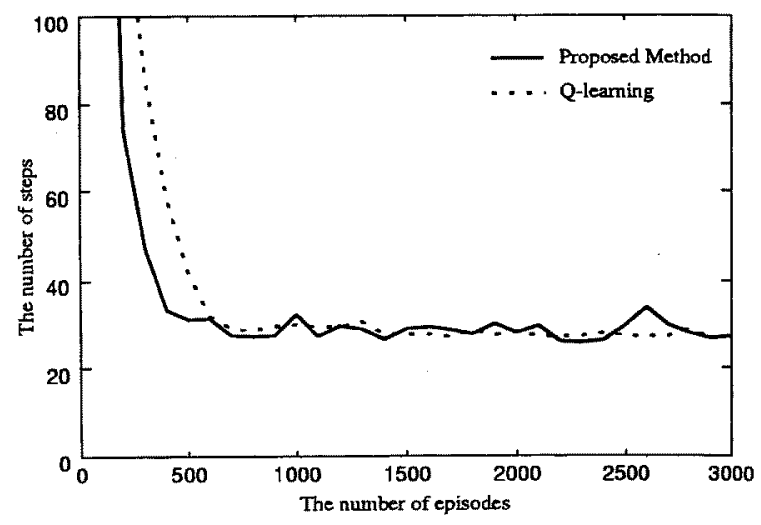

図 10 平均所要ステップ数（環境 B)

Fig. 10. Average number of required steps (Environment $B$ ).

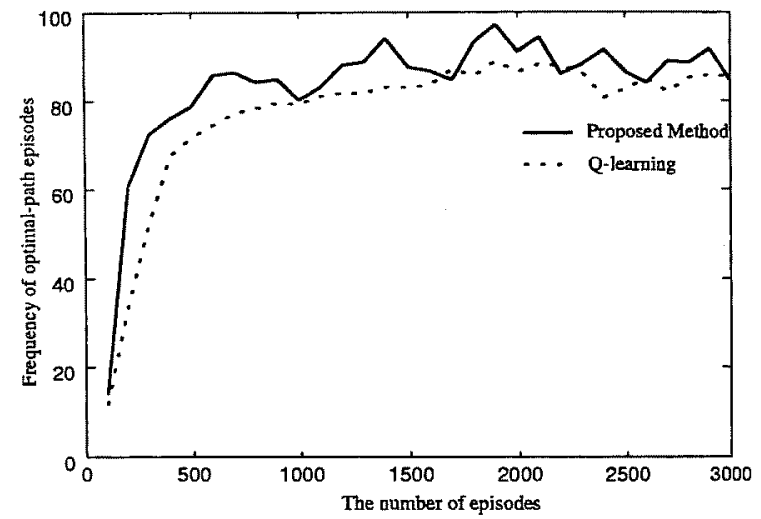

図 11 最適政策の獲得頻度（環境 B)

Fig. 11. Frequency of acquiring the optimal policy (Environment B).

以上では，学習済の入力ゲートを用いた場合に強化学習 が高速化されることを確認したが，入力ゲートの学習に必 要な時間コストは反映されていない。ゲート学習のための 計算時間増加分と, 学習高速化による時間減少分のいずれ が大きいかはタスクに依存する。しかし，ゲート学習は 1 回行えばよいので，学習後のゲートが同様に有効である類

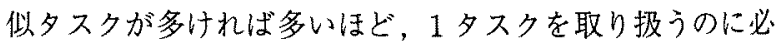
要な時間コストの中でゲート学習時間が占める割合は低下 する。

\section{6.おわりに}

本論文では入力にゲートを設けた入力ゲート付きニュー ラルネットワークと，それをエージェントの行動学習に応 用する手法を提案した。人力ゲートは，ある夕スクにおけ る学習から, 入力の要不要とその状況依存性を把握するこ とができる。これにより，設計者が必要な入力情報を指定 する負担を少なくすることができる。すなわち，ある程度 必要であろうという情報を入力として与文ておけば，入力 
ゲートにより不要な入力による状態の分岐を防ぎ，学習に 対して適当な状態を割り当て，効率よく学習ができる。さ らに, 状況に依存する入力の要不要は類似夕スクにおける 強化学習の高速化に利用することができる。シミュレーショ ン結果から強化学習エージェントの状態を決定する入力情 報を状況に応じて使い分け，学習を高速化できることが確 認できた。またゲートの開度から, どの入力がエージェン トの行動に強く関わっているのかを容易に知ることができ るため, 必要な入力情報について解釈が容易になる。

(平成 13 年 4 月 16 日受付, 同 14 年 2 月 7 日再受付)

\section{文献}

(1) T. Unemi: "Reinforcement learning", J. of Japanese Soc. for Artificial Intelligence Vol.9, No.6, pp.830-836 (1994-6) (in Japanese)

畧見達夫: 強化学習, 人工知能学会誌, 9, 6, pp.830-836 (1994-6)

（2）山村雅幸·宮崎和光·小林重信：強化学習の特徴と発展の方向, シ ステム / 制御/情報, 39，4，pp.191-196（1995-4）

(3) R.S. Sutton and A.G. Barto: Reinforcement Learning, A Bradford Book (1998)

(4) O. Abul, F. Plat, and R. Alhaji: "Multiagent reinforcement learning using function approximation", IEEE Trans. on Syst., Man, and Cyber.-Part C: Appli. Rev., Vol.30, No.4, pp.485-497 (2000-11)

(5) K. Terada, T. Nakamura, H. Takeda, and T. Nishida: "A cognitive robot architecture based on tactile and visual information", Advanced Robotics, Vol.13, No.8, pp.767-777 (2000)

(6) H. Yajima, K. Ohkura, and K. Ueda: "Evolutionary Acquisition of Reinforcement Learning Frame for Multi-agent The Balance of Global Reward and Indivisual Reward -", Preprint of 10th Intelligent Systems Symposium pp.291-293 (2000-10) (in Japanese)

矢島英明·大倉和博·上田完次: 進化的手法によるエージェント群 の強化学習フレーム獲得一大域的報酬と個別的報酬のバランスに関 する考察-, 第 10 回インテリジェント・システム・シンポジウム講 演論文集, pp.291-293 (2000-10)

(7) C.J.C.H. Watkins and P. Dynan: "Q-Learning", Machine Learning, Vol.8, pp.279-292 (1992)

(8) J.Murata: "Artificial neural networks with input gates", T. IEE Japan, Vol.121-C, No.1, pp.127-133 (2001-1) (in Japanese)

村田純一: 入力ゲート付きニューラルネットワーク, 電学論誌, 121-C, 1, pp.127-133 (2001-1)

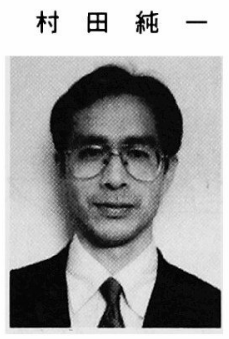

(正員) 1986 年 3 月九州大学大学院工学研究科 電気工学専攻博士後期課程修了, 工学博士。同年 4 月より同大学工学部助手。ぞの後, 同助教授を 経て, 現在同大学大学院システム情報科学研究院 助教授。ニューラルネットワークを中心とする学 習・自己組織化システムとその応用に関する研究 に従事。計測自動制御学会, システム制御情報学 会, IEEEの会員。

鈴 木 政 史 (非会員) 1999 年 3 月九州大学工学部電気工学

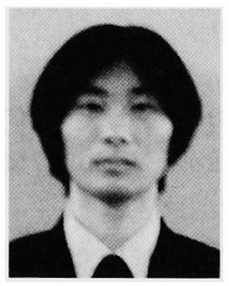
科卒業。2001 年 3 月, 同大学大学院システム情 報科学研究科電気電子システム工学専攻修了。同 年 4 月, ソニー (株) 入社。

平

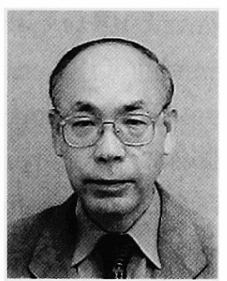

(正員) 1964 年 3 月九州大学工学部電気工学科卒 業。1966 年 3 月同大学大学院工学研究科修士課 程電気工学専攻修了。同年 4 月（株）日立製作所 入社 日立研究所勤務, 1989 年 8 月同研究所副所 長。1991 年 8 月同大みか工場主管技師長。1992 年 12 月九州大学工学部教授, 1996 年 5 月同大学 院システム情報科学研究科教授。2002 年 9 月早 稲田大学大学院情報生産システム研究科教授, 現 在に至る。計測自動制御学会, 電気学会, 情報処理学会, IEEEの各 会員。工学博士。 